\title{
Prenatal Screening for Co-Inheritance of Sickle Cell Anemia and $\beta$-Thalassemia Traits
}

Dipali Dhawan*, Spandan Chaudhary, Khyati Chandratre, Arpita Ghosh, Niraj Sojitra, Sandip Hirapara, Sanjay Singh and Prashanth G Bagali Xcelris Labs Ltd., Old Premchand Nagar Road, Bodakdev, Ahmedabad, Gujarat, India

\begin{abstract}
Co-inheritance of sickle cell anemia and $\beta$-thalassemia traits require medical attention. Individuals with sickle cell and $\beta$-thalassemia disorders produce abnormal form of hemoglobin or decreased synthesis or complete absence of the $\beta$-globin chains of hemoglobin. Therefore, affected individuals might require blood transfusions at regular intervals. Prenatal diagnosis of fetal hemoglobinopathy should be offered when the fetus is at risk of being affected. The aim of this study was to assess the applicability of the nucleotide sequencing method in the identification of both diseases and to identify and counsel asymptomatic parents to make reproductive choices. We demonstrate the ability to detect these traits in a family, which was suspected to be carrying $\beta$-thalassemia mutations as per the clinician.
\end{abstract}

Keywords: $\beta$-thalassemia; Sickle cell anemia; Co-inheritance; Prenatal diagnosis; Nucleotide sequencing method

\section{Introduction}

Sickle cell disease and $\beta$-thalassemia are among the most common inherited genetic disorders worldwide caused by mutations in the $\beta$-globin (HBB) gene [1]. Both genetic disorders have an autosomal recessive mode of inheritance and usually the child must inherit an abnormal gene from both parents to have the disease. If one of the parents has a sickle cell trait and the other parent is a carrier for $\beta$-thalassemia, there is a $25 \%$ chance that the fetus will co-inherit both these traits. The type of sickle cell trait $\mathrm{HbE}, \mathrm{HbS}$ or $\mathrm{HbC}$ depends on the genetic variation present. Approximately $50 \%$ of all severe $\beta$-thalassemia cases worldwide are due to Hemoglobin E ( $\mathrm{Hb} \mathrm{E}) / \beta$-thalassemia [2]. The clinical manifestation of this disease is quite variable, due to mutations observed for $\beta$-thalassemia. Hence, the phenotype would range from a mild and asymptomatic anemia to a severe condition requiring blood transfusions from early childhood.

The clinical and hematological parameters in patients with $\mathrm{HbE} /$ $\beta$-thalassemia vary from patient to patient [3-7]. The phenotypic variability of this co-inheritance and the lack of understanding of the possible mechanisms have imposed greater challenges in the management of $\mathrm{Hb} \mathrm{E} / \beta$-thalassemia affected individuals [8].

Based on the probable genetic and environmental factors, researchers have tried to classify the type of $\mathrm{Hb} \mathrm{E} / \beta$-thalassemia into "severe" and "mild" forms. The genotype of the $\beta$-globin gene mutation has been reported to determine the severity of co-inherited sickle cell mutation [9]. It has been observed that the absence of synthesis of $\beta$-globin chain $\left(\beta^{0}\right)$ caused severe disease condition, leading to transfusion dependency throughout the life time of the affected individuals. In case of the reduced synthesis of $\beta$-globin chain $\left(\beta^{+}\right)$, a milder clinical disease was observed, which might be microcytic but not anemic $[3,10]$.

Genetic counseling services are recommended for individuals and families with sickle cell $\beta$-thalassemia diseases on the nature, inheritance and implications of genetic disorders to help them make informed medical and personal decisions. Sickle cell and $\beta$-thalassemia carriers or affected individuals should be counselled before and after marriage to highlight potential risks involved in the future pregnancies. However, the scarce knowledge in this area warrants further research on the understanding of the effect of combined genotypes on the phenotype in different population groups. This will enable improved therapeutic regime for affected individuals and help in better patient management. The aim of this study was to assess the applicability of the nucleotide sequencing method in the identification of both diseases and to identify and counsel asymptomatic parents to make reproductive choices.

\section{Case Report}

The specific cases of a family presented in the report are citizens of South East Asian country. A 35 year old woman (mother of a 12 year old female), who is expecting a second child was referred to our laboratory for genetic testing of $\beta$-thalassemia mutations. The age of her husband was reported to be 39 years. Clinician had counselled the family about the relevance and the outcome of genetic test. The clinician had performed the amniocentesis procedure, and the collected amniotic fluid sample was sent to Xcelris Labs for genetic testing of $\beta$-thalassemia mutations. Very minimal patient history was shared and it did not mention any underlying genetic disorders in the family. We reconfirmed with the clinician about the availability of patient consent form in the hospital or clinic. Also, it was made clear to the Clinician and parents that Xcelris Labs abides by the Pre-Conception and PreNatal Diagnostic Techniques (PC \& PNDT) Act of Government of India.

Nucleotide sequencing of the targeted region covering all the frequently observed and clinically significant $\beta$-thalassemia mutations was carried out for the trio samples (maternal blood, paternal blood and amniotic fluid of fetus) in our laboratory. After the analysis, it was observed that the father was heterozygous for one of the $\beta$-thalassemia mutations, namely, c. $92+5 \mathrm{G}>\mathrm{C}$ (IVS I-5 G>C) (Figure 1) and the mother was not carrying any $\beta$-thalassemia mutations. However, we observed a heterozygous mutation, namely, c.79G>A (Figure 2),

*Corresponding authors: Dipali Dhawan, Xcelris Labs Ltd., Old Premchand Nagar Road, Opposite Satyagrah Chhavani, Bodakdev, Ahmedabad, Gujarat, India, E-mail: dipali.dhawan@xcelrislabs.com

Received December 02, 2015; Accepted December 07, 2015; Published December 15, 2015

Citation: Dhawan D, Chaudhary S, Chandratre K, Ghosh A, Sojitra N, et al. (2016) Prenatal Screening for Co-Inheritance of Sickle Cell Anemia and $\beta$-Thalassemia Traits. Clin Med Biochem 2: 108. doi:10.4172/2471-2663.1000108

Copyright: () 2016 Dhawan D, et al. This is an open-access article distributed under the terms of the Creative Commons Attribution License, which permits unrestricted use, distribution, and reproduction in any medium, provided the original author and source are credited. 
Citation: Dhawan D, Chaudhary S, Chandratre K, Ghosh A, Sojitra N, et al. (2016) Prenatal Screening for Co-Inheritance of Sickle Cell Anemia and $\beta$-Thalassemia Traits. Clin Med Biochem 2: 108. doi:10.4172/2471-2663.1000108

responsible for the $\mathrm{Hb} \mathrm{E}$ trait of sickle cell anemia in the mother.

When the DNA extracted from the amniotic fluid was analyzed, we observed that two mutations, which were found in the parents, were co-inherited to the fetus. Genotypic condition of the fetus for both mutations were heterozygous mutation [c.92+5G $>$ C (IVS I-5 G>C)] for beta thalassemia (Figure 3) and heterozygous mutation [c.79G>A (Hb E)] for sickle cell anemia (Figure 4).

In order to confirm laboratory findings, we asked the referring clinician to send detailed clinical history and relevant medical tests performed by the parents. It was observed from the medical records that the parents had undergone the hemoglobin electrophoresis test for themselves and their first child (then, was 2 years old). It was clear from the hemoglobin electrophoresis test reports that the father was $\beta$-thalassemia minor, mother was $\mathrm{HbE}$ carrier and the first child suffered from $\mathrm{HbE} / \beta$-thalassemia disease (Table 1 ). Based on our laboratory test results, we concluded that fetus is carrier for $\mathrm{HbE}$ and $\beta$-thalassemia. However, the $\beta$-thalassemia mutation type, namely, c. $92+5 \mathrm{G}>\mathrm{C}$ (IVS I-5 G>C) is of $\beta^{+}$type and might cause a mild form of $\beta$-thalassemia disease. The fetus is also carrier for $\mathrm{HbE}$ trait for sickle cell anemia. The pedigree chart shows the autosomal inheritance pattern of sickle cell anemia and $\beta$-thalassemia traits (Figure 5).

\section{Discussion}

Sickle cell anemia and $\beta$-thalassemia are genetic disorders caused by different genetic mutations [11]. Therefore, patients can develop both conditions simultaneously. Patients who have sickle cell/ $\beta$ thalassemia typically have symptoms similar to sickle cell anemia, though the intensity of the anemia can vary depending on the severity of the thalassemia [12]. Increased research in population genetics of hematological disorders over the past few years have enabled better understanding of the genetic factors responsible for progression and severity of anemia in $\mathrm{Hb} \mathrm{E} / \beta$-thalassemia [13]. The type of $\beta$-thalassemia mutation co-inherited with $\mathrm{Hb} \mathrm{E}$, the co-inheritance of alpha $(\alpha)$ thalassemia, and polymorphisms associated with increased synthesis of fetal hemoglobin; are some of the genetic factors influencing the clinical course of this disease [14].

Diagnosis of sickle cell disease and $\beta$-thalassemia are well established by isoelectric focusing (IEF) and high performance liquid chromatography (HPLC) [15]. HPLC can be used to detect common $\beta$-globin (HBB) pathogenic variants involving qualitative abnormalities (i.e., abnormal hemoglobins), but not quantitative abnormalities such as thalassemia's. The easiest way to diagnose combined sickle cell $/ \beta$ thalassemia diseases is to perform protein based gel electrophoresis or cellulose acetate electrophoresis. In this method, different kinds of hemoglobin are segregated and separated in the gel, which will allow laboratories or doctors to identify and quantify the amounts of sickle cell and normal hemoglobin cells [11].

Nucleotide sequencing analysis is a highly recommended method to detect pathogenic variants associated with sickle cell anemia and $\beta$-thalassemia hemoglobin variants, simultaneously. In case of real time PCR based single gene disorder assay for $\beta$-thalassemia screening, there is great risk of missing sickle cell anemia disease or trait, although, sickle cell mutation is present in the same $\beta$-globin gene. Nucleotide sequencing covers a larger target region and can detect unexpected and/ or novel variants which can be missed by target specific probe based real time PCR technologies [16]. Hence, nucleotide sequencing proves to be an advantageous method over real time PCR based detection especially in cases like this wherein the parents are asymptomatic.

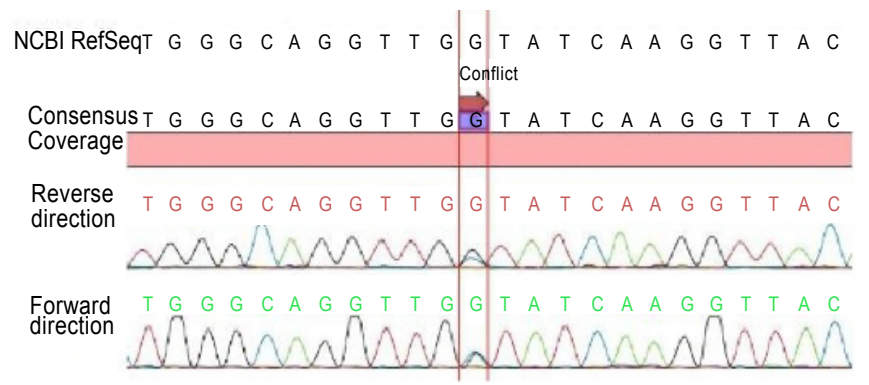

Figure 1: Electropherogram of bidirectional sequencing analysis demonstrated heterozygous mutation [c. $92+5 \mathrm{G}>\mathrm{C}$ (IVS I-5 G>C)] for $\beta$-thalassemia in Father's blood sample.

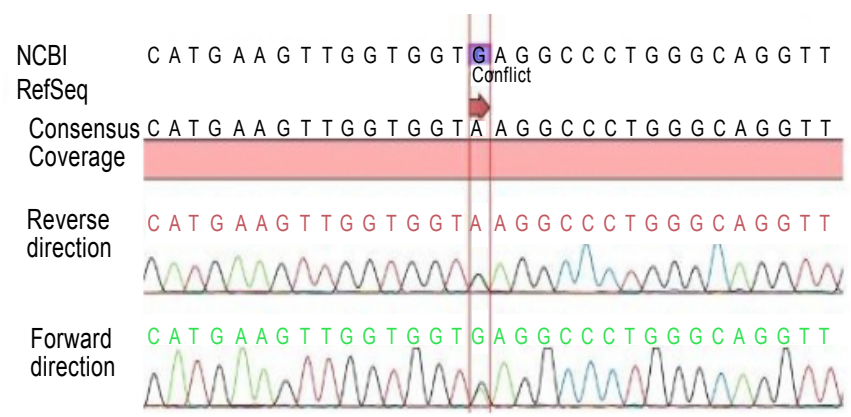

Figure 2: Electropherogram of bidirectional sequencing analysis demonstrated heterozygous mutation [c.79G >A ( $\mathrm{HbE})$ ] for sickle cell anemia in Mother's blood sample.

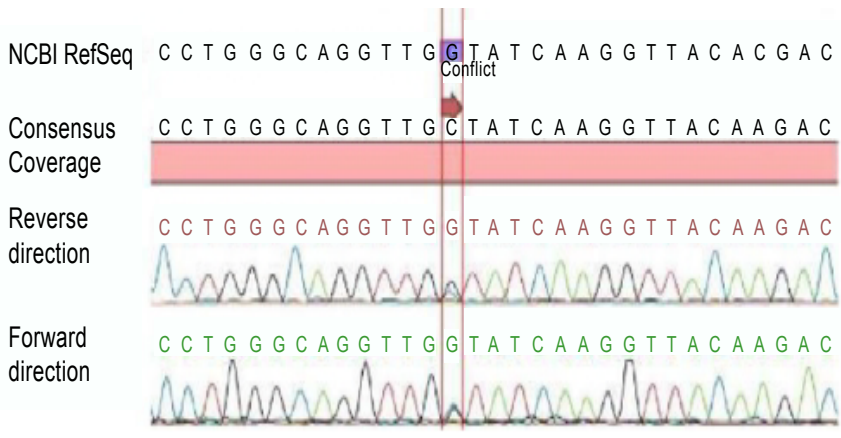

Figure 3: Electropherogram of bidirectional sequencing analysis demonstrated heterozygous mutation [c. $92+5 \mathrm{G}>\mathrm{C}$ (IVS $\mathrm{I}-5 \mathrm{G}>\mathrm{C}$ )] for $\beta$-thalassemia in Fetal DNA (amniotic fluid) sample.

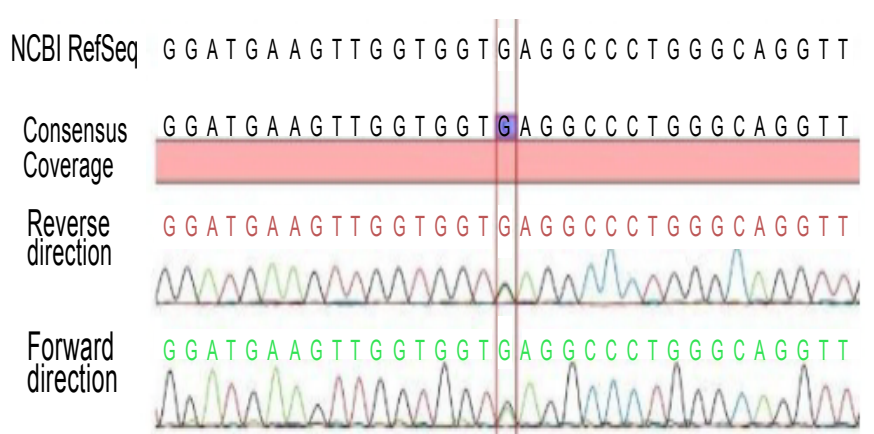

Figure 4: Electropherogram of bidirectional sequencing analysis demonstrated heterozygous mutation [c.79G $>A(\mathrm{HbE})]$ for sickle cell anemia in Fetal DNA (amniotic fluid) sample. 
Citation: Dhawan D, Chaudhary S, Chandratre K, Ghosh A, Sojitra N, et al. (2016) Prenatal Screening for Co-Inheritance of Sickle Cell Anemia and $\beta$-Thalassemia Traits. Clin Med Biochem 2: 108. doi:10.4172/2471-2663.1000108

Page 3 of 3

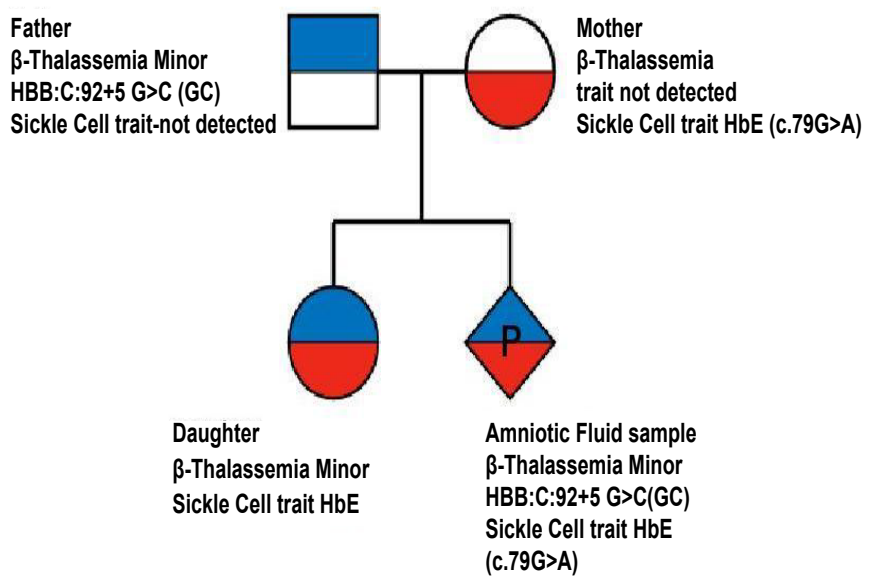

Figure 5: Pedigree chart depicting the autosomal recessive inheritance pattern of $\beta$-thalassemia and sickle cell anemia traits in the family.

\begin{tabular}{|c|c|c|c|c|c|}
\hline Sample Source & Fraction & $\begin{array}{c}\% \text { of } \\
\mathrm{Hb}\end{array}$ & g/dL & $\begin{array}{c}\text { Normal } \\
\text { value (\%) }\end{array}$ & Inference \\
\hline \multirow[t]{2}{*}{ Mother } & $\mathrm{HbA}$ & 71.7 & 7.2 & $96.5-100$ & \multirow[t]{2}{*}{ HbE trait } \\
\hline & $\mathrm{HbE}$ & 28.3 & 2.9 & $0.0-0.0$ & \\
\hline \multirow[t]{2}{*}{ Father } & $\mathrm{HbA}$ & 94.4 & 12.5 & $96.5-100$ & \multirow{2}{*}{$\begin{array}{c}\beta \text {-thalassemia } \\
\text { minor }\end{array}$} \\
\hline & $\mathrm{HbA} 2$ & 5.6 & 0.7 & $1.0-3.5$ & \\
\hline \multirow{3}{*}{$\begin{array}{l}\text { First child (test done at } \\
\text { age } 2 \text { years), present } \\
\text { age } 12 \text { years }\end{array}$} & $\mathrm{HbA}$ & 8.4 & 0.4 & $96.5-100$ & \multirow{3}{*}{$\begin{array}{c}\mathrm{HbE} / \beta- \\
\text { thalassemia }\end{array}$} \\
\hline & $\mathrm{HbF}$ & 46.9 & 2.3 & $0.0-2.0$ & \\
\hline & $\mathrm{HbE}$ & 44.7 & 2.2 & $0.0-0.0$ & \\
\hline
\end{tabular}

Table 1: Values observed during hemoglobin electrophoresis and its inference.

Our approach of performing prenatal testing for pathogenic variants responsible for $\beta$-thalassemia and sickle cell disease on trios sample, confirmed the co-inheritance of sickle cell trait along with $\beta$-thalassemia mutation in the fetus.

We strongly recommend that prenatal screening of fetus (using chorionic villus sampling or amniotic fluid or cell free fetal DNA from maternal blood) for these mutations should be mandatory, if any one of the parents or siblings are known carrier and the another parent's genetic profile is unknown and/or blood sample is unavailable for testing.

\section{References}

1. Modell B, Darlison M (2008) Global epidemiology of haemoglobin disorders and derived service indicators. Bull World Health Organ 86: 480-487.

2. Fucharoen S, Weatherall DJ (2012) The Hemoglobin E Thalassemia's. Cold Spring Harb Perspect Med 2: a011734.

3. Weatherall DJ, Clegg JB (2001) Thalassemia Syndromes. 4th edn. Blackwell Scientific Publications, Oxford. pp: 1-846.

4. George E, Wong HB (1993) Hb E beta +-thalassemia in west Malaysia: clinical features in the most common beta-thalassemia mutation of the Malays [IVS 1-5 (G-->C)]. Singapore Med J 34: 500-503.

5. Piplani S (2000) Hemoglobin E disorders in the north east India. J Assoc Physicians India 48: 1082-1084.

6. Winichagoon $P$, Thonglairoam $V$, Fucharoen $S$, Wilairat $P$, Fukumaki $Y$, et al (1993) Severity differences in beta-thalassemia/haemoglobin $E$ syndromes: implication of genetic factors. Br J Haematol 83: 633-639.

7. Fucharoen $S$, Ketvichit $P$, Pootrakul $P$, Siritanaratkul N, Piankijagum A, et al (2000) Clinical manifestation of beta-thalassemia/hemoglobin $E$ disease. $J$ Pediatr Haematol Oncol 22: 552-557.

8. Weatherall DJ (1998) Hemoglobin E beta-thalassemia: an increasingly common disease with some diagnostic pitfalls. J Pediatr 132: 765-767.

9. Mukherjee MB, Nadkarni AH, Gorakshakar AC, Ghosh K, Mohanty D, et al. (2010) Clinical, hematologic and molecular variability of sickle cell- $\beta$ thalassemia in western India. Indian J Hum Genet 16: 154-158.

10. Fucharoen S, Winichagoon $P$ (2000) Clinical and hematologic aspects of hemoglobin $\mathrm{E}$ beta-thalassemia. Curr Opin Haematol 7: 106-112.

11. Cao A, Galanello R (2010) Beta-thalassemia. Genetics in Medicine 12: 61-76.

12. Adewoyin AS (2015) Management of Sickle Cell Disease: A Review for Physician Education in Nigeria (Sub-Saharan Africa). Anemia 2015: 791498.

13. Musallam KM, Taher AT, Cappellini MD, Sankaran VG (2013) Clinical experience with fetal hemoglobin induction therapy in patients with $\beta$-thalassemia. Blood 121: 2199-2212.

14. Olivieri NF, Pakbaz Z, Vichinsky E (2011) Hb E/beta-thalassemia: a common and clinically diverse disorder. Indian J Med Res 134: 522-531.

15. Bender MA, Seibel GD (2014) Sickle cell disease. In: Gene Reviews, Pagon RA, Adam MP, Ardinger HH, et al. editors, Seattle, WA, University of Washington, Seattle: 1993-2015.

16. Sankaran VG, Gallagher PG (2013) Applications of high-throughput DNA sequencing to benign hematology. Blood 122: 3575-3582.
Citation: Dhawan D, Chaudhary S, Chandratre K, Ghosh A, Sojitra N, et al. (2016) Prenatal Screening for Co-Inheritance of Sickle Cell Anemia and $\beta$ Thalassemia Traits. Clin Med Biochem 2: 108. doi:10.4172/2471-

2663.1000108 